\title{
ESTETIKA TARI PIRIANG SULUAH DI NAGARI GUNUANG PADANGPANJANG SUMATERA BARAT
}

\author{
Mila Susanti ${ }^{1 *}$, Erlinda $^{2^{*}}$ \\ Minat Studi Pengkajian Seni Tari Program Pascasarjana \\ Institut Seni Indonesia Padangpanjang \\ Jl. Bahder Johan, Guguak Malintang, Padangpanjang, Kota Padangpanjang, 27126. \\ Sumatera Barat. Indonesia \\ Email: miellacwaith@gmail.com
}

\begin{abstract}
Abstrak
Tari Piring Suluah merupakan tarian tradisi yang terdapat di Nagari Gunuang Padangpanjang. Tari Piring Suluah ini ditarikan oleh laki-laki maupun perempuan berjumlah genap 2 sampai 10 orang, memakai properti piring yang diujung jari tengahnya dipasang cincin yang terbuat dari dama atau buah kemiri dan Suluah yang menyala diletakkan di atas kepala dengan membawakan gerak-gerak tari yang bersumber dari manusia, alam, dan binatang. Suluah merupakan penerangan masyarakat Gunuang sebelum masuknya listrik. Tari Piring Suluah ditarikan untuk upacara adat seperti pengangkatan panggulu (pemimpin adat), pesata kawinan, kitanan dan acara alek nagari. Tujuan penelitian ini adalah mengungkap nilai estetika yang terkandung dalam tari Piriang Suluah di Nagari Gunuang Padangpanjang Sumatera Barat. Tari ini khasnya menggunakan Suluah yang diletakkan di atas kepala. Metode yang digunakan adalah metode kualitatif, pengumpulan data dilakukan melalui observasi dan mengamati pertunjukan Tari Piring Suluah. Hasil penelitian ini mengungkapkan bentuk, estetika yang terdapat dalam tari Piring Suluah. Nilai estetika tari Piring Suluah tercermin pada unsurunsur yang membentuk tari Piring Suluah, yaitu adanya gerak, penari, properti, pola lantai, rias busana, musik, dan tempat pertunjukan.
\end{abstract}

Kata Kunci: piring suluah, estetika , nagari gunuang.

\begin{abstract}
Suluah Plate Dance is a traditional dance found in Nagari Gunuang Padangpanjang. The Suluah Piring Dance is danced by even men and women of 2 to 10 people, using a property of a plate on which the middle finger is placed on a ring made of dama or candlenut and Suluah which are lit above the head by bringing dance movements sourced from humans, nature and animals. Suluah is the lighting of the Gunuang community before the entry of electricity. Suluah Piring Dance is danced for traditional ceremonies such as the appointment of the pelulu (traditional leader), marriage ceremony, kitanan and the alek nagari event. The purpose of this study was to reveal the aesthetic values contained in the Piriang Suluah dance in Nagari Gunuang Padangpanjang West Sumatra. This dance is typical of using Suluah which is placed on the head. The method used is a qualitative method, data collection is done through observation and observing the performance of the Suluah Plate Dance. The results of this study reveal the aesthetic form found in the Suluah Plate dance. The aesthetic value of the Suluah Plate dance is reflected in the elements that make up the Suluah Piring dance, namely the existence of movement, dancers, property, floor patterns, dress makeup, music, and the venue.
\end{abstract}

Keywords: suluah plate, aesthetics, nagari gunuang.

\section{PENDAHULUAN}

Minangkabau masih banyak ditemui tari tradisional yang masih mempertahankan pola-pola budaya tradisi dalam penyajian dan aktivitas tari dimaksud. Tari tradisional Minangkabau yang berkembang dipedesaan atau nagari maupun kampung-kampung, secara bentuk dan penyajiannya hadir dalam berbagai versi. Masing-masing tarian tersebut menggambarkan nilai-nilai tradisi setempat dengan keindahan yang khas. Nilai keindahan yang khas pada masyarakat di sebut dengan istilah estetika. Menurut (Indrayuda, 2001:12) estetika tari Minangkabau terletak pada bentuk gerak yang agresif, stakato dengan gerak yang patah-patah, lintasan gerak, dan dinamika geraknya. Di samping itu, pada bagian lain nilai estetika tari Minangkabau juga terletak pada gaya tari Minangkabau, yang berakar pada ketangkasan dan kewaspadaan teknik pencak silat. 
Minangkabau mempunyai perbedaan sesuai dengan nagari di mana kesenian itu tumbuh dan berkembang. Hal ini disebabkan karena pertumbuhan dan perkembangan seni budaya Minangkabau terdapat di dua daerah, yaitu daerah darek dan daerah pesisir. Masing-masing daerah menunjukan ciri khas dalam perwujudan tari tradisionalnya. Menurut Jasselin dalam Asmaniar.dkk (2002: 53) bahwa Minangkabau terdiri dari dua daerah, pertama oleh orang Minangkabau disebut darek, ke dua pasisia.

Minangkabau mempunyai berbagai macam tari, seperti tari Pasambahan, Silat, tari Piring dan Randai yang teknis penyajiannya ditampilkan dengan pengembangan unsur gerak serta gaya yang berbeda, yang menunjukan ciri khas daerahnya masing-masing. Minangkabau memiliki berbagai tari tradisio-nal, di antaranya adalah tari Piriang. Tari Piring merupakan salah satu ikon tari yang populer di Minangkabau, sebab hampir seluruh negeri di Minangkabau memiliki tari Piriang tradisional. Adapun tari Piriang tersebut seperti tari Piring Suluah di Nagari Gunuang Padangpanjang.

Tari Piring adalah kesenian yang ada disetiap nagari atau desa di Minangkabau. Tari piring dimulai masyarakat agraris, dimana hampir seluruh nagari mempunyai tari piring dengan ciri khasnya masingmasing. Menurut A.A. Navis, karateristik tari Piring digolongkan dalam kesenian darek yang menggambarkan para petani dengan hasil panen yang melimpah (Navis, 1989: 80). Tarian ini menggambarkan rasa kegembiraan musim panen tiba. Para pemuda mengayunkan gerak langkah dengan menunjukkan kebolehannya memainkan piring di tangannya yang ditampilkan dengan ekpresi wajah penuh perasaan gembira. Adapun penggunaan properti piring, menggambarkan hasil panen yang mencukupi penduduk setempat, yang diungkapkan dengan ekpresi rasa gembira, yang sangat atraktif dan unik dalam memainkan piring dengan tanpa takut jatuh. Dari sekian banyak tari piring yang hidup di nagari-nagari di Minangkabau, yang menarik untuk dibahas adalah tari piring yang hidup di Nagari Gunuang yang diberi nama oleh masyarakat setempat "Tari Piring Suluah" sebagai bentuk kesenian yang hidup dan berkembang saat sekarang.

Piriang Suluah memvisualisasikan berbagai aktivitas para petani saat sedang mengolah lahan persawahannya. Aktivitas tersebut antara lain, meniti pematang, menyiangi jerami, mengikat kerbau dan menghalau burung. Penari tari Piriang Suluah ini mempunyai keunikan yaitu, selain memainkan piriang di tangan, penari juga membawa Suluah yang diletakkan di atas kepala. Kemudian para penari menari berkeliling melalui deretan piring yang disusun membentuk lingkaran.

Tari Piring sebagai salah satu produk kesenian, merupakan salah satu hasil upaya budi manusia yang menumbuhkan keindahan. Kesenian merupakan produk budi manusia yang sarat dengan unsur estetika. Sehingga kesenian dapat memunculkan sesuatu nilainilai keindahan yang menyenangkan manusia. Seperti halnya tari Piring Suluah, dengan memunculkan nilainilai keindahan tari Piring Suluah telah memesona indera mata masyarakat Nagari Gunuang dan sekitarnya. Estetika yang muncul dalam tari Piring Suluah tidak terlepas dari nilai dan norma adat istiadat masyarakat Nagari Gunuang dan sekitarnya. Menurut Gie (1976: 15,17,19) Aesthetica berasal dari bahasa Yinani yang berarti hal-hal yang dapat diserap dengan panca indra. Selanjutnya Gei menjelaskan bahwa keindahan dalam seni mempunyai hubungan yang erat dengan kemampuan manusia menilai karya seni tersebut. Sasaran estetika menurut Gie adalah indah dan jeleknya sesuatu menurut ukuran atau norma estetika tertentu dalam masyarakat. Pengertian penserapan panca indra dalam tari Piring Suluah yang berasal dari Nagari Gunuang berkaitan dengan visualisasi dari semua unsur taru tersebut.

Berdasarkan penjelasan di atas, dapat disimpulkan, ada beberapa rumusan masalah untuk mengungkap estetika tari Piring Suluah yang terdapat di Nagari Gunuang Padangpanjang Sumatera Barat, Rumusan masalah dari penelitian ini yaitu :

1. Bagaimana bentuk dari tari Piring Suluah di Nagari Gunuang Padangpanjang Sumatera Barat

2. Bagaimana bentuk estetika tari Piring Suluah di Nagari Gunuang Padangpanjang Sumatera Barat

Tujuan dari penelitian ini adalah untuk mengetahui

1. Bentuk dari tari Piring Suluah yang terdapat di Nagari Gunuang Padangpanjang Sumatera Barat.

2. Estetika tari Piring Suluah di Nagari Gunuang Padangpanjang Sumatera Barat.

\section{KAJIAN TEORI}

Pemecah dari masalah tersebut diperlukan teori-teori yang berkaitan yaitu Teori estetika yang dikemukakan oleh Djelantik mengatakan bahwa estetika adalah suatu ilmu yang mempelajari semua aspek yang disebut keindahan. Maka keindahan yang dimaksud bukan hanya keindahan yang bersifat tampak saja, melainkan juga keindahan yang bersifat tidak nampak 
(abstrak). Selanjutnya juga dikatakan bahwa semua benda atau peristiwa keseniang mengandung tiga aspek dasar, yakni: wujud atau rupa, bobot atau isi dan penampilan (Djelantik, 2004:15).

Sedangkan Teori bentuk yang dikemukakan Jacqueline Smith mengatakan bahwa bentuk adalah wujud keseluruhan dari sistem, maksudnya keseluruhan dari unsur-unsur tari itu membentuk suatu rangkaian yang menyatu. Penyatuan tersebut mempunyai daya pikat pada pengembangan sampai klimaks, pesan pokok yang disampaikan dari penyajian tari itu akan dilihat secara keseluruhan. Wujud keseluruhan dari sitem tari adalah hal yang menggambarkan bentuk (Smith, 1985:34). Adanya unsur gerak, pola lantai, kostum, penari, properti, musik pengiring, rias, dan ekspresi merupakan sebuah bentuk kesatuan yang membentuk tari menjadi bentuk tarian yang utuh. Penyatuan hal tersebut adalah hal yang dinikmati dalam satu kemasan pertunjukan dan pesan serta mksud dari tarian itu akan tercapai.

\section{METODE PENELITIAN}

Penelitian ini berupa penelitian kualitatif adalah metode penelitian yang dilakukan untuk meneliti pada kondisi obyek yang alamiah, (sebagai lawanya adalah eksperimen) dimana penelitian ini sebagai instrumen kunci, teknik pengumpulan data dilakukan secara gabungan (Sugyiono, 2015: 247). Penelitian kualitatif adalah penelitian yang objeknya alamiah. Objek yang alamamiah adalah objek yang berkembang apa adanya, tidak dimanipulasi oleh peneliti dan kehadiran peneliti tidak mempengaruhi dinamika pada objek tersebut. Penelitian ini menggunakan kualitatif yang bersifat deskriptif, sehingga data yang dikumpulkan berbentuk kata-kata atau gambar. Peneliti mengunakan jenis penelitin kualitatif dikarenakan metode ini membantu untuk menggumpulkan data yang benar- benar nyata saat dilapangan dan membantu menemukan masalah dalam penelitian, metode kualitatif dapat menghasilkan informasi yang akurat, dalam penelelitian ini peneliti ingin mendiskripsikan tentang permasalahan yang ada dilapangan. Meneliti bagaimana estetika dari Tari Piriang Suluah di Nagari Gunuang Padangpanjang, Metode ini juga dapat mengumpulkan data dari beberapa yaitu hasil wawancara dan observasi.

\section{HASIL DAN PEMBAHASAN}

\section{Hasil}

Propinsi Sumatera Barat atau daerah Minangkabau memiliki berbagai tari tradisional, di antranya adalah tari Piring. Tari piring merupakan salah satu ikon tari yang populer di Minangkabau, sebab hampir seluruh
Gorga Jurnal Seni Rupa

Volume 08 Nomor 01 Januari-Juni 2019

p-ISSN: 2301-5942 | e-ISSN: 2580-2380

negeri di Minangkabau memiliki tari Piring tradisional. Salah satunya tari Piring Suluah yang ada di Nagari Gunuang Padangpanjang. Suluah meruapakan alat penerangan tradisional dengan bahan bakar minyak tanah yang dipakai masyarakat gunuang sebelum masuknya listrik.

Tari Piriang Suluah merupakan tari yang menceritakan atau gambaran dari aktivitas atau kebiasaan masyarakat di nagari Gunuang, yang mayoritas mata pencarian penduduknya adalah petani. Tari Piriang Suluah memvisualisasikan berbagai aktivitas para petani saat sedang mengolah lahan persawahannya, jika masyarakat kemalaman pulang dari sawah, maka masyarakat selalu membawa Suluah kemudian diletakkannya di atas kepalanya, kemudian kedua tangan mereka membawa alat-alat yang mereka pakai saat bertani. Dalam gelapnya malam, Suluah memberikan mereka arah dan penerang untuk meniti pematang sawah. Aktvitas tersebut digambarkan lewat tari yang bernama tari Piriang Suluah.

Awal mulanya tari Piriang Suluah ini di ciptakan untuk rasa syukur masyarakat nagari Gunuang terhadap panen padi mereka yan: Kemudian tari Piriang Suluah ini ditan 139 ah. upacara adat seperti upacara pengangkaıan peıуıulu atau alek nagari yang ditampilkan di halaman tempat penobatan penghulu tersebut atau di jalan yang akan dilalui oleh penghulu bersama pemangku adat dan tetamu agung. Tari ini juga digunakan untuk hiburan rakyat yang dipertunjukan di luar ruangan atau di arena, maupun di bangsal atau balai adat.

\section{Pembahasan}

Tari Piriang Suluah berasal dari Nagari Gunuang Padangpanjang Sumatera Barat, tarian ini gerak dasarnya adalah gerak-gerak silat sehingga terbentuklah tari Piriang Suluah (Wawancara Asnimar, 16 Februari 2016). Sedangkan piring yang digunakan sebagai alat atau properti dalam tarian ini, dan tempurung kemiri yang telah dilobangi isinya digunakan sebagai penghasil bunyi yang mana dari dentingan piring dengan kulit damar yang dilobangi tengahnya tersebut akan menghasilkan bunyi piring yang menimbulkan suasana kegembiraan sesudah panen padi. Suluah dijadikan sebagai penerangan bagi masyarakat Nagari Gunuang. Kemudian piring dan Suluah pun dijadikan pelengkap dalam tari ini, yang kemudian terbentuklah tari Piring Suluah. Dan dari dulu hingga saat ini gerakan dalam tari Piring Suluah ini masih dilakukan dengan gerakan-gerakan yang sama kecuali ada sedikit penambahan dari alat musik dan kostumnya. 


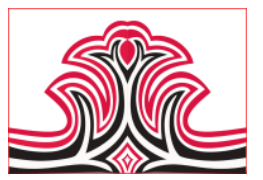

Adapun yang menarik pada tari ini adalah properti yang digunakan berupa piring dan Suluah. Suluah dengan api menyala diletakkan di atas kepala penari, hal ini menjadi keunikan tersendiri dalam tari Piring Suluah. Di sini penari dituntut selain lincah memainkan piring, dia juga harus menjaga keseimbangan Suluah di atas kepala. Makna simbolik yang ingin disampaikan adalah makna kepercayaan diri dan tanggung jawab. Dalam pertunjukkannya tari Piring Suluah ditarikan oleh penari laki-laki dan perempuan berjumlah genap, enam sampai sepuluh orang. Penari menggunakan properti piring yang di ujung jari tengahnya dipasang cincin yang terbuat dari tempurung dama atau buah kemiri, dan Suluah yang menyala diletakkan di atas kepala, sambil menarikan gerak-gerak sederhana.

Pertunjukan Tari Piring Suluah biasanya ditampilkan untuk penyambutan tamu-tamu dan upacara adat (perta perkawinan, pengangkatan pengulu dan kitanan). Pertunjukan tari secara keseluruhan mempunyai bentuk pertunjukan itu sendiri, sebagaimana Jacqualine Smith mengatakan bahwa bentuk adalah wujud, dan struktur sesuatu yang dapat dibedakan dari materi yang ditata (Jacqualine Smith terjemahan Ben Soeharto, 1995:15). Bentuk pertunjukan suatu tari tiadak dapat lepas dari kandungan bentuk dan pertunjukan itu sendiri. Selanjutnya pertunjukan tari tidak hanya pada rangkaian gerak tetapi akan lebih menarik bila dilihat secara keseluruhan (1995: 30). Berdasarkan pengertian di atas bentuk pertunjukan tari Piring sama halnya dengan bentuk dari keseluruhan isi, maka bentuk tari Piring ini dimaksudkan sebagai wujud dan penyajian atau pertunjukan dimaksudkan sebagai sesuatu yang disajikan atau ditampilkan. Jadi bentuk pertunjukan tari Piring adalah wujud tari secara keseluruhan yang ditampilkan kepada penonton. Adapun bentuk pertunjukan tari Piring Lampu Suluah dalam bahasan ini merupakan perpaduan antara gerak, penari, properti, pola lantai, rias busana, musik dan tempat pertunjukan yang membentuk satu kesatuan yang utuh. Uraian masingmasing aspek dalam konteks bentuk pertunjukan ini dapat diuraikan sebagai berikut:

\section{1).Gerak}

Gerak merupakan unsur terpenting dalam sebuah tari. Tari tidak akan terwujud tanpa adanya gerak dari penari yang mendukung sebuah pertunjukan tersebut. Soedarsono mengatakan bahwa "tanpa gerak belum bisa dikatakan sebagai sebuah tari, karena tari adalah ekspresi jiwa manusia yang dilahirkan melalui gerak
Gorga Jurnal Seni Rupa

Volume 08 Nomor 01 Januari-Juni 2019

p-ISSN: 2301-5942 | e-ISSN: 2580-2380

yang ritmis dan indah (Sodarsono,1977:17). Gerakan dalam tari Piriang Sulauah merupakan gambaran keseharian masyarakat Nagari Gunuang yang mayoritas mata pencariannya adalah bertani. Gerak tari yang dilakukan seperti menirukan gerakan binatang, gerakan keseharian serta gerakan-gerakan langkah pencak silat. Gerak-gerak tersebut adalah gerak meniti pematang, mangiriak jarami, mangisai jarami, ramo-ramo tabang, mahalau buruang dan tapuak rangik.

\section{2).Penari}

Sebuah pertunjukan tari, penari merupakan pelaku utama yang memiliki peran penting. Arthur S. Nalan mengatakan peran penari sebagai media ungkap tari sangat tepat jika penari disebut sebagai ujung tombak yang berada digaris depan, berhadapan langsung dengan penonton.(1996:3). Penari dapat membuat daya tarik tersendiri bagi penonton yang menyaksikan pertunjukan. Untuk keberhasilan sebuah pertunjukan tari, harus didukung oleh tingkat kemampuan penari dalam melakukan gerak tari. Seperti halnya dalam pertunjukan tari Piriang Suluah kelihaian penari dalam memaiinkan piring di tangan mereka dan melakukanatraksi pijak piring dengan tekhnik yang telah diajarkan oleh Asnimar dan Syahrial. Penari dari tari Piriang Suluah ini tidak ditentukan berapa jumlah penari, laki-laki atau perempuan dan anak-anak sampai dewasa. Penari memain memaikan piring dengan cara memutar-mutar pergelangan tangan dengan piring di telapak tangan dengan Suluah di atas kepala menjaga keseimbangan dan konsentrasi dalam menarikannya.

\section{3).Musik}

Musik dalam sebuah tarian bukan hanya sekedar iringan akan tetapi musik adalah pengiring dari tari yang tidak bisa ditinggalkan. Musik dalam tari dibagi dua yaitu: musik internal dan musik eksternal. Musik internal adalah musik yang berasal dari dalam diri si penari secara langsung apakah itu suara dendang, hentakan kaki, tepuk tangan dan sebagiannya. Musik eksternal adalah musik yang berasal dari luar dari penari yaitu suara musik yang ditimbulkan oleh alat musik seperti : talempong, gandang tambua, tasa.

Tari Piriang Suluah yang sudah dikembangkan oleh Asnimar dan Syahrial dari segi musik mengalami perubahan karena dulunya alat musik yang digunakan hanya talempong dan saluang, sedangkan sekarang alat musik pengiring tari Piriang Suluah yaitu gandang tambua, talempong, saluang, sarunai, tasa dan juga vokal dari penari Piriang Suluah. 


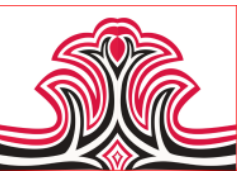

4).Properti

Properti adalah alat yang digunakan sebagai perlengkapan dari sebuah pertunjukan. Menurut Robby Hidayat properti merupakan suatu bentuk peralatan penunjang gerak wujud ekspresi. Maka dari itu identitasnya sebagai alat atau peralatan bersifat fungsional (Hidayat, 2011:54). Properti yang digunakan dalam tari Piriang Suluah yaitu mengguanakan piring makan yang berukuran sedang yang sering disebut orang piring tujuh dan cincin yang terbuat dari damar atau buah kemiri dan Suluah di atas kepala. Semua penari memegang piring di tangan kanan dan kirinya dengan cincin di ujung telunjuk mereka. Guna cincin untuk dijentikan ke piring supaya mengasilkan bunyi. Salah satu dari penari membawa Suluah di atas kepalanya. Suluah yang terbuat dari botol kaca yang berisikan bahan bakar minyak tanah.

\section{5).Tempat Pertunjukan}

Tempat pertunjukan yang sering disebut pentas atau panggung adalah tempat diadakannya suatu pertunjukan atau penampilan. Tempat pertunjukan atau pentas terbagi 2 macam, yaitu pentas proscenium dan pentas arena. Menurut Robby Hidajat pentas proscenium adalah pentas yang penontonnya berhadapan langsung dengan penari atau penonton yang menyaksikan pertunjukan dari arah depan, sedangkan pentas arena adalah pentas yang berada di tengah-tengan penonton yaitu penontonnya berada di sekeliling pentas (2011:104). Pada pertunjukan tari Piriang Suluah menggunakan kedua macam pentas ini, yaitu karena tari Piriang Suluah dapat dipertunjukan di pentas proscenium dan pentas arena.

Keindahan tari akan dapat dilihat melalui pertunjukannya sebagaimana yang diungkapkan oleh Djelantik bahwa untuk menetapkan estetika semua benda atau peristiwa kesenian adalah mengandung tiga unsur dasar, yaitu: wujud atau rupa, bobot atau isi, dan penampilan atau penyajian ( Djekantik, 2004: 15). Ketiga aspek ini akan dirujuk untuk membahas estetika tari Piring Suluah di Nagari Gunuang Padangpanjang selanjutnya.

\section{(1).Wujud}

Wujud menurut A. A. M. Djelantik mengacu pada kenyataan yang nampak secara kongkrit (berarti dapat dipersepsi dengan mata atau telinga) maupun kenyataan yang tidak tampak secara kongkrit, yang abstrak hanya bisa dibayangkan, seperti sesuatu yang diceritakan atau yang dibaca dalam buku (Djelantik, 2004: 17). Sehubungan dengan hal tersebut di atas, tari Piring Suluahadalah sesuatu kenyataan yang nampak secara kongkrit, seperti gerak, penari,
Gorga Jurnal Seni Rupa

Volume 08 Nomor 01 Januari-Juni 2019

p-ISSN: 2301-5942 | e-ISSN: 2580-2380

properti, pola lantai, rias dan busana, musik dan tempat pertunjukan. Sedangkan yang tidak tampak terlihat pada gerak yang mempunyai makna.

Gerak tari Piring Suluah di Nagari Gunuang Padangpanjang dijadikan sebagai media utama untuk mengungkapkan keinginan- keinginan maupun pengalaman dari masyarakatnya. Dengan adanya keinginan dari masyarakat mereka, maka masyarakatnya pun menciptakan gerak-gerak tari Piring Suluah yang telah ditata, serta memiliki keindahan yang dapat dirasakan oleh masyarakatnya.

\section{a.Gerak Maniti Pamatang}

Gerak maniti pamatang merupakan gambaran seorang penati sedang meniti pematang sawah atau berjalan di tepi sawah dengan berhati-hati. Merupakan gerakan pembuka dari tari ini penari berjalan sambil memaikan piring seolah berjalan ditepian pematang sawah. Estetika dari gerakan ini adalah dengan gerakan tanngan diayun kedepan dan kebelakan dengan kaki sedikit tekuk dan berjalan pelan-pelan, sehingga menggambarkan bagaimana seseorang yang berjalan dengan hati-hati.

\section{b.Gerak Ramo-Ramo Tabang}

Gerakan ramo-ramo tabang ini merupakan gambaran dari gerakan binatang kupu-kupu beterbangan di sawah yang sedang mencari makan.Gerakan yang memutar piring dengan pergelangan tangan membentuk angka delapan sambil mengelilingi deretan pirng yang disusun berbentuk lingkaran. Estetika dari gerakan ini membentuk kebersamaan saling tolong menolong dalam panen yang digambarkan dari gerakan yang melingkar menghadap ke dalam.

\section{c.Gerak Mengikat Tali Jawi}

Gerakan ini merupakan gambaran dari kegiatan seseorang yang sedang menggulung tali sapi atau mengikatkan tali sapi mereka supaya sapi mereka tidak lepas. Estetika dari gerak ini bagaimana kelincahan penari memainkan piring memutar piring dengan gerakan keatas ke bawah kaki bergerak kedepan ke belakang.

\section{d.Gerakan Mengisai Jerami}

Gerakan mengisai jerami merupakan gambaran seseorang sedang mangisai jerami (memisahkan padi dari batangnya). Menggambarkan bagaimana petani siap panen dengan cara memisahkan padi dari batantnya. Estetika yang terdapat dalam gerak ini penari jongkok di atas deretan piring menghadap ke dalam, tangan kanan dan kiri bergeraka dengan folum yang besar menghadap serong kiri dan kanan bergantian. 


\section{e.Gerakan Maalau Buruang}

Gerakan maalau buruang merupan gambaran dari seorang petani mengusir burung supaya tidak memakan padi mereka di sawah. Bagaimana petani menjaga tanamanya dari hama yang mengganggu tanaman mereka. Estetika dari gerakan ini adalah mengayunkan tangan dari arah belakang sampai kedepan dengan volume garak yang besar. Dengan kaki pitunggua.

\section{f.Gerakan Mairiak Padi}

Gerakan mairiak padi merupakan gerakan yang menggambarkan seorang petani di sawah yang memisahkan padi dari batangnya dengan menginjakijak padi dan mimisahkan padi yang berisi dengan padi yang kosong. Estetika dari gerak ini yaitu kelincahan gerakan kaki penari melompat lompat dan dan tangan memaikan piring di depan dada keatas kebawah secata bergantian.

\section{g.Gerakan Tapuak Rangik}

Gerakan tapuak rangik merupakan gambaran seorang petani yang membunuh atau memukul nyamuk agar tidak menggigit mereka yang sedang bekerja di sawah. Nyamuk yang mengganggu sedang bekerja di sawah maka dari itu adanya gerak dari memukul nyamuk dengan kedua telapak tangan atau menepuk nyamuk. Estetika dari gerakan ini yaitu merupakan gerakan penutup dari Tari Piring Suluah. Mempertemukan tangan kiri dan kana yang sedang memegang piring dengan tenaga tetapi juga membutuhkan kontrol dan kosentrasi sehingga pecahan piringnya tidak mengenai penonton atau penari lainnya.

\section{(2).Bobot}

A.A.M. Djelantik mengatakan bahwa suasana dapat ditonjolkan sebagai unsur utama dalam bobot karya tersebut (Djelantik, 2004: 52). Pada tari Piring Suluah yang dimaksud sejalan dengan pengertian dan tujuan tari tersebut sebagai simbol kekaraban antara penari dan masyarakat penonton. Dalam tari ini yang lebih ditonjolkan atraksi dari penari yang memainkan piring serta Suluah yang sedang menyala di atas kepala. Bagaimana penari tetap menari memainkan piring di tangan serta menjaga keseimbangan Suluah yang ada di kepala dan menjanganya supaya tetap hidup.

\section{(3).Penampilan}

Menurut A.A.M. Djelantik, tiga unsur yang berperan dalam penampilan adalah : bakat, keterampilan, sarana atau media (Djelantik, 2004: 65). Penari tari Piring Suluah merupakan masyarakat Nagari Gunuang Padangpanjang yang berbakat ingin melestarikan kesenian yang ada di daerah mereka. Mereka mempunyai keterampilan seperti mencari kiat-kiat
Gorga Jurnal Seni Rupa

Volume 08 Nomor 01 Januari-Juni 2019

p-ISSN: 2301-5942 | e-ISSN: 2580-2380

menampilkan pertunjukan yang memukau, memberikan atraksi yang atraktif dengan melalukan laithan yang sesui dan tepat waktu atau disiplin. Sarana dan media bersifat sederhana, dari rias bisana dan kostum sederhana hanya saja menyesuaikan tempat pertujukan atau kebutuhan panggung saja.

\section{KESIMPULA DAN SARAN \\ 1.Kesimpulan}

Estetika tari Piring Suluah terdiri dari dua aspek yaitu wujud dan bobot. Dapat disimpulkan wujud dalam bentuk dana susunan gerak pada tari Piring Suluah secara teks dan konteks memiliki estetika yang berasaskan keindahan yang terkait pada nilai kultural masyarakat nagari Gunuang atau masyarakat nagari Gunuang dan sekitarnya. Sehingga khasanah gerak tetap mencerminkan pola kehidupan masyarakat nagari Gunuang yang mayoritas adalah petani.

Unsur pendukung juga tidak terlepas dari khasanah budaya lokal, sehingga tari Piring Suluah dapat dikatakan estetis oleh masyarakat nagari Gunuang, disebabkan karena di dalam tarian tersebut telah terkandung unsur-unsur budaya lokal, yang akrab dengan naluri seni dan filsafah hidup masyarakat. Sehingga tari Piring Suluah ini dapat dinikmati dari unsur estetika oleh masyarakat pendukungnya.

\section{Saran}

Berkaitan dengan penelitian mengenai tari Piring Suluah yang terdapat di nagari Gunuang Padangpanjang, harus tetap melestarikan dan memerhatikan keberlanjutan kebudayaan maupun kesenian tradisional yang terdapat di daerah kita. Sangatlah penting untuk tetap melestarikannya supaya tidak tergerus oleh zaman. Penulis berharap pemerintah berperan terhadap kesenian tradisi yang ada di daerah-daerah terutama tari Piring Suluah yang ada di nagari Gunuang Padangpanjang Sumatera Barat.

\section{DAFTAR RUJUKAN}

A.A.M. Djelantik. (2004). Estetika Sebuah Pengantar. BAndung: MSPI.

A.A. Navis. (1989). Seni Minangkabau Tradisional Sumbangan Budaya dalam Pembangunan Nasional.Jakarta: Majalah Analisis Kebudayaan.

Arthur S. Nalan. (1996). Aspek Mausia dalam Seni Pertunjukan. Nadung: STSI Bandung.

Daryusti. (2001). Hegemini Penghulu dalam Perspektif Budaya. Yogyakarta: Perpustakaan Nasional.

Gie, The Liang. 1976. Garis Besar Estetika (Filsafat 
Keindahan). Yogyakarta: Karya.

Indrayuda. (2012). Eksistensi Tari Miangkabau.

Padang: UNP Press.

Jacqualine, Smith. (1995). Dance Compotition And

Practical Guide For Teacher, terjemahan

Ben Suharto, Komposisi Sebuah Pertunjukan

Praktis Bagi Guru. Yogyakarta: IKASTI.

Robby, Hidajat. (2011). Koreografi dan Kreatifitas.

Yagyakarta: Kendil Media Pustaka Seni

Indonesia.

Soedarsono. (1977). Tari-Tarian Indonesia I. Jakarta:

Proyek Pengembangan Media Kebudayaan.

Sugiono. (2005). Penelitian Kulitiatif.

Bandung: Alfabeta. 